\title{
The Correlation Between Self Care Behavior and the Level of Hba1c of the Patients with Diabetes Mellitus Type 2 in Binjai City, Sumatera Utara Province
}

\author{
Rina Amelia ${ }^{1}$, Harun Alrasyid Damanik ${ }^{2}$, Dharma Lindarto ${ }^{3}$, Erna Mutiara ${ }^{4}$ \\ ${ }^{1}$ Department of Public Health, Faculty of Medicine, University of Sumatera Utara, Indonesia \\ drrinaamelia@gmail.com \\ ${ }^{2}$ Department of Nutrition, Faculty of Medicine, University of Sumatera Utara, Indonesia \\ harunalrayidraffiilyahoo.com \\ ${ }^{3}$ Departmenf of Internal Medicine Faculty of Medicine, University of Sumatera Utara, Indonesia \\ Dharmalindarto22@gmail.com \\ ${ }^{4}$ Department of Demography and Biostatistics, Faculty of Public Health, University of Sumatera Utara, Indonesia \\ Erna mutiara@yahoo.com
}

\begin{abstract}
Diabetes has become the fastest growing chronic disease in the world. Therefore, in order to manage it, behavioral changes in lifestyle including physical activity, dietary, monitoring of blood glucose levels (BGL), and obedience to treatment are needed. A good self care (self-management) of patients with diabetes will help them manage the disease. American Association of Diabetes (ADA) suggest people with diabetes type 2 to have selfcare behaviors that can improve their quality of life while reducing the complications associated with the disease (Bonner et al., 2016). The aim of the research was to analyze the correlation between self care behaviors and HbA1c levels of the patients with type 2 diabetes in Binjai, North Sumatra Province. The design of the research was descriptive analytic with cross sectional approach. The population in this study was all patients with type 2 diabetes mellitus in eight community health centers in Binjai. The samples were consecutive sampling of 118 people who meet the criteria. Data gathered were analyzed using Pearson Correlation. The result of this study suggested that the majority of samples (102 people or $86.4 \%$ ) with type 2 diabetes mellitus in Binjai has low attention to do self care behavior. The average HbA1c level of the diabetic patients was $9.8 \%$ (uncontrolled). Meanwhile, the result of the Pearson Correlation Test showed a correlation between self care behaviors and HbA1c level in diabetes patients in Binjai $(p<0.05)$. The better the self-care behavior of the diabetes patients the lower the HbA1C levels is. Self-care behavior is the determinant factor of the controllable diabetes. To improve self-care behavior, cooperation between doctors and health workers to provide continuing education is essential in order to increase understanding and independence of the patients with type 2 diabetes.
\end{abstract}

Keywords - Self care behavior, HbA1C levels, patients with DM Type 2, education, glycemic control

\section{INTRODUCTION}

Diabetes mellitus (DM) Type 2 is a metabolic disease that its prevalence is increasing worldwide and reducing life expectation of the patients [1]. As a progressive chronic disease, the patients of DM need to be lifelong treatment and its complications affect the quality of their life [2]. A person suffering from DM has a lower quality of life than a person with no chronic illnesses [1]. To manage DM needs behavioral and lifestyle changes including physical activity, dietary, monitoring of blood glucose levels, and obedience to treatment. The Quality of life of a person living with type 2 diabetes can be improved by implementing self-management education (self care). According to the American Association of Diabetes (ADA), it is very important for people with diabetes type 2 to have self-care behavior in order to improve their quality of life while reducing the complications associated disease [3].

Diabetes self-care is an individual action taken to control diabetes that includes treatment and prevention of complications ([4]. Meanwhile, Reference [5] defines diabetes self-care as a person's ability to perform self-care and do self care diabetes measures to improve blood glucose control. Self care behavior compels patients to change their previous unhealthy life pattern to be a healthier lifestyle with the help and strict monitoring of health workers to 
make it successfully [6]. Sustainable self care basically can shape the way of life of a person in preventing, recognizing, and managing the disease s/he suffers from. Therefore, good and sustainable self-care behaviors might increase the state of wellbeing by implementing appropriate care in accordance with patients' conditions [7].

The implementation of self-care behaviors gives a good effect to diabetic patients as the disease will be controlled. To monitor the disease is being controlled or not, laboratory examination has to be performed to determine the evidences. One of the parameters used to analyze long-term diabetes is HbA1c. The HbA1c can be used to assess the quality of long-term glycemic control and the effectiveness of the therapy. The HbA1c examination can describe the average of daily based blood glucose level and the degree of carbohydrates balance within two months, monitor the progress of the disease, and know the development of diabetes complications. The examination of the HbAlc is better than that of the fasting blood glucose. As a result, the HbA1c examination should be performed at least two times a year [8].

The higher the value of HbA1c, the higher the possibility of the patients will have complications. Every $1 \%$ reduction in HbA1c levels, the risk to get microvascular blood vessel disorders reduces by $35 \%$, the risk to get other complications decreases by $21 \%$, and the risk of death reduces by $21 \%$. Therefore, the appropriate and discipline implementation of self-care is one of the costeffective management of diabetes because it can significantly reduce the risk of complications [9]. It is important to be noticed that diabetes be greatly decrease the quality of life due to its complications [10].

According to the American Association of Diabetes Educators [11], there are seven essential behaviors of self care: Healthy eating (healthy diet), being active (enough physical activity), monitoring (blood glucose control), taking medicine (antidiabetic medication or insulin), problem solving, healthy coping, and reducing risk. The seven behaviors have a positive correlation with controllable blood glucose levels, reduce complications, and improve the quality of life of patients with diabetes.

\section{RESEARCH METHODS}

The objective of the research was to analyze the correlation between self care behavior and $\mathrm{HbA} 1 \mathrm{c}$ level of the patients with type 2 diabetes in Binjai, North Sumatra Province. The design of the research was descriptive analytic with cross sectional approach. Prior to this research, the study protocol was approved by the research ethics committee in the Faculty of Medicine University of North Sumatra/Universitas Sumatra Utara (USU) and all participants willing to participate in the study have signed a written informed consent. The population in this study was all patients with type 2 diabetes mellitus who regularly have their disease checked in the eight community health centers in the city of Binjai. The samples were consecutive sampling of 118 people who met the criteria. Data were collected directly (primary data) covering self-care behaviors and HbA1c level of the patients. To determine the self-care behavior, modified questionnaire based on SDSCA (The Summary of Diabetes Self-Care Activities) consisting of 14 questions about diet, exercise, blood glucose monitoring, medication, and foot care were developed. To determine the level of Hbalc, trained laboratory personnel took patients' venous blood and did laboratory based analysis to determine its level. The HbAlc examination was conducted using affinity Doronad + Modified HPLC. The data gathered were analyzed using statistical test of Pearson Correlation Test.

\section{RESEARCH RESULT}

\section{A. Characteristics of the Patients with Type 2 Diabetes \\ TABLE I \\ CHARACTERISTICS OF PATIENTS BY SEX}

\begin{tabular}{|c|c|c|}
\hline Gender & Frequency (person) & Percentage (\%) \\
\hline Male & 29 & 24.6 \\
\hline Female & 89 & 75.4 \\
\hline Total & $\mathbf{1 1 8}$ & $\mathbf{1 0 0}$ \\
\hline
\end{tabular}

Table 1 shows that the majority of the patients with type 2 diabetes who have their disease checked in the 8 community health centers in the city of Binjai was female ( 89 women or $75.4 \%$ ) 
B. Characteristics of Diabetic Patients by Age Group

TABLE II

CHARACTERISTICS OF DIABETIC PATIENTS BY AGE GROUP

\begin{tabular}{|c|c|c|}
\hline Age (years) & $\begin{array}{c}\text { Frequency } \\
\text { (person) }\end{array}$ & Percentage (\%) \\
\hline $\begin{array}{c}\text { Early adulthood } \\
\text { (26-35 years) }\end{array}$ & 1 & 0.8 \\
\hline $\begin{array}{c}\text { End Adulthood } \\
\text { (36-45 years) }\end{array}$ & 9 & 7.6 \\
\hline $\begin{array}{c}\text { Early Elderly } \\
\text { (46-55 years) }\end{array}$ & 39 & 33.1 \\
\hline $\begin{array}{c}\text { End Elderly } \\
\text { (56-65 years) }\end{array}$ & 50 & 42.4 \\
\hline Elderly (>65 years) & 19 & 16.1 \\
\hline Total & $\mathbf{1 1 8}$ & $\mathbf{1 0 0}$ \\
\hline
\end{tabular}

Table 2 shows that the majority (50 people or $42.4 \%$ ) of the diabetes patients falls into the age group of end elderly (56-65 years).

\section{Characteristics of Diabetic Patients According to Education}

TABLE III

CHARACTERISTICS OF DIABETIC PATIENTS ACCORDING TO EDUCATION

\begin{tabular}{|c|c|c|}
\hline Education Level & $\begin{array}{c}\text { Frequency } \\
\text { (person) }\end{array}$ & $\begin{array}{c}\text { Percentage } \\
(\mathbf{\%})\end{array}$ \\
\hline Do not complete primary school & 5 & 4.2 \\
\hline Graduated from primary school & 22 & 18.6 \\
\hline Junior High School & 28 & 23.7 \\
\hline High School & 37 & 31.4 \\
\hline Academy/University & 26 & 22.0 \\
\hline Total & $\mathbf{1 1 8}$ & $\mathbf{1 0 0}$ \\
\hline
\end{tabular}

The result exhibited in Table 3 shows that the majority (37 people or $31.4 \%$ ) of the diabetes patient has education level of high school.

D. Self Care Behavior of The Patients of Type 2 Diabetes

TABLE IV

SELF CARE BEHAVIOR OF DIABETES PATIENTS

\begin{tabular}{|c|c|c|}
\hline Self Care Behavior & $\begin{array}{c}\text { Frequency } \\
\text { (person) }\end{array}$ & $\begin{array}{c}\text { Percentage } \\
(\mathbf{\%})\end{array}$ \\
\hline High & 16 & 13.6 \\
\hline Low & 102 & 86.4 \\
\hline Total & $\mathbf{1 1 8}$ & $\mathbf{1 0 0}$ \\
\hline
\end{tabular}

Table 4 shows that self care behaviors of the patients with type 2 diabetes in Binjai is dominated by a low level behavior as many as 102 people $(86.4 \%)$.

E. HbA1c LEVEL OF TYPE 2 DIABETES PATIENTS

TABLE V

LEVELS OF HbA1C DIABETES PATIENTS

\begin{tabular}{|c|c|c|}
\hline Category & $\begin{array}{c}\text { Frequency } \\
\text { (person) }\end{array}$ & $\begin{array}{c}\text { Percentage } \\
(\mathbf{\%})\end{array}$ \\
\hline Well controlled & 26 & 22.0 \\
\hline Less controlled & 86 & 72.9 \\
\hline Total & $\mathbf{1 1 8}$ & $\mathbf{1 0 0}$ \\
\hline
\end{tabular}

Table 5 categorizes the number of patients suffering from type 2DM after having their HbA1c analyzed. The result shows that 86 people or $72.9 \%$ falls into category of less controlled patients.

\section{F. Correlation Between Self Care Behavior And HbAiC Levels Of The Patients With Diabetes}

TABLE VI

CORRELATION BETWEEN SELF CARE BEHAVIOR AND HbA1C LEVEL

\begin{tabular}{|c|c|c|}
\hline $\begin{array}{c}\text { Measurement } \\
\text { Results }\end{array}$ & Mean & r, p value \\
\hline Self care & 62.6 & $\mathrm{r}:-0,412 ;$ \\
\cline { 1 - 2 } HbA1c & $9.8 \%$ & $\mathrm{p}: 001(\mathrm{p}<0.05)$ \\
\hline
\end{tabular}

Table 8 exhibits that the mean of self-care behaviors of the patients with type 2 diabetes mellitus in Binjai is 62.6 (less behavior); while, the mean of HbA1c level is $9.9 \%$ (uncontrolled). Meanwhile, the result of the Pearson Correlation Test is $r:-0412$ with $p$ value: 0.001 , so it can be concluded that there is a correlation between self care behaviors and $\mathrm{HbA} 1 \mathrm{C}$ levels in the patients with Type $2 \mathrm{DM}$ in Binjai. In this case, the negative correlation value means that the better the behavior of Type 2 diabetic patients the lower HbA1C levels will be.

\section{IV.DISCUSSION}

Self Care Behavior of the Patients with Type 2 Diabete The results of the study revealed that 102 people or $86.4 \%$ of the diabetes patients had a low level self care behavior. This finding was in line with the research result conducted of [7]) at the Endocrine Clinic DR Hasan Sadikin that the majority of patients $(55.91 \%)$ belong to low level self care. Meanwhile Reference [12] conducted a research to 
assess diabetic patients' understanding about selfcare knowledge, concluded that in general the level of self-care behavior of diabetic patients is poor (unsatisfactory). Although the significance varies among countries, less optimum self-care behaviors among DM patients nearly exist in all countries. Only $46 \%$ of patients with Type 1 and $39 \%$ of patients with Type 2 succeed in performing of at least two-thirds self-care behavior [13].

Low level self-care behavior of DM patients in this study might be caused by lack of understanding about the disease among diabetic patients. From the interviews with the DM patient, it could be concluded that most of the diabetes patients in the clinic in Binjai did not knowledge about diet, exercise, and the importance of taking regular medication. Most patients only came to the clinic and got the prescription. They did not understand that they had to be active and kept controlling the blood glucose level to avoid its complications.

\section{A. HbAlC levels}

The study concluded that based on the HbA1C examination the majority of Type $2 \mathrm{DM}$ patients in Binjai categorized into uncontrolled patient was 86 people or $72.9 \%$. The high level of HbA1c in the patients with Type 2 DM in Kota Binjai might be due to the lack of ability in carrying out education given by health workers. As the four pillars of diabetes management were not applied in everyday life, consequently, the uncontrolled BGL caused high levels of $\mathrm{HbA1C}$.

The purpose of having $\mathrm{HbA1c}$ checked was to describe the status of the daily average of blood glucose level and the average degrees of daily carbohydrates balance within two months, to monitor the progress of the disease, and to know the development of diabetes complications. Therefore, the HbA1c was better than the fasting blood glucose. As a result, HbA1c examination should be performed at least 2 times a year as the higher the value of the HbAlc, the riskier the patients to get complications [8]. The reduction of every $1 \%$ of HbA1c level could reduce the risk of getting microvascular blood vessel disorders by $35 \%$, decrease $21 \%$ of other complications, and reduce the risk of death by $21 \%$. The normality of $\mathrm{HbA} 1 \mathrm{c}$ could be achieved by maintaining a normal blood glucose level all the time. A high glucometer of the patients with type 2 diabetes after being tested indicated the implication of high HbAlc level. The high glucometer was caused by the intake of food that did not comply with the recommended diet or the patients never do exercise. High HbAlc level was caused by prolonged accumulation of glucose level. $\mathrm{HbA1c}$ is slowly formed in the post-translational and the process is slowly taken place and is not influenced by the enzyme along the path of life of erythrocytes; therefore, if the erythrocyte is old, the $\mathrm{HbA1c}$ level is higher than young erythrocytes [8] [14].

\section{B. Correlation between Self Care Behaviors and HbAlc} levels of the DM patients with Type 2 Diabetes Patients

The study concluded that there was a correlation between self-care behaviors and $\mathrm{HbA} 1 \mathrm{C}$ levels in the patients with Type 2 DM in Binjai. The negative result of the correlation value meant that the better the behavior of Type 2 diabetic patients the lower (closer to normal values) the HbA1C level. Several studies suggested the same conclusion that self care is closely associated with health status of the diabetic patients. Research conducted in the clinic Endocrine Hospital Hasan Sadikin shows a significant relationship between the level of self care and $\mathrm{HbA1C}$ levels in the patients who come to the clinic [7].

Meanwhile, research conducted by [15] suggested that there is a relationship between self-care, selfefficacy, and social support and HbA1C levels in public health centers in Boyolali of Central Java. Self-care in diabetes requires patients to modify their lifestyle that can be done with the help of health workers [16]. Self-care behavior becomes one of the essential components for patients with type 2 diabetes because this behavior will help patients maintain and improve their health status.

People with chronic diseases such as diabetes should consider self-care behavior necessary during their lifetime and that includes the most important activities such as eating a healthy and balanced food, follow-up medical therapy, continuous glucose monitoring to adjust the diet, controllable activity level, and following the medication prescription. Implementing right lifestyle strategies and self-care is a key element in the prevention of diabetes that 
might cause more severe complications [17]. Pients with diabetes who carry out the self care behavior regularly every day will have an impact on their health as suggested by Reference [18] who identifies the significant decrease in $\mathrm{HbAlc}$ levels in the first 3 months with a total follow-up of 12 months in the patients who do adherence to self care program. She found that there is $0.7 \%$ decline in blood glucose level in the majority of the participants (59.5\%).

Reference [19] examined 213 samples of those joining a training of self-care diabetes including exercise, nutrition, blood glucose monitoring, and insulin injection settings and within six months the level of the HbA1c in the blood of the samples were measured found that there is a significant difference between before and after training.

Reference [20] investigated the difference between DM patients who performed treatment belief and those who performed healthy behavior related to the therapeutic efficacy of DM found that healthy behaviors lead to better adherence to treatment than patients who simply perform therapy. Meanwhile, this study found that the improved knowledge about A1C of the patients decreased the A1C level of the patients. This result is consistent with the research finding of [21] revealing that patients with DM who perform diabetes self-care can directly control their blood glucose level by changing their lifestyle following health education they get.

\section{CONCLUSION}

The conclusion of this research is that there is a significant correlation between self-care behaviors and $\mathrm{HbA} 1 \mathrm{C}$ level of the patients with Type $2 \mathrm{DM}$ in Binjai; the better the behavior of the Type 2 diabetic patients the more normal HbA1C levels will be. The Self-care behavior is the determining factor of the uncontrolled diabetes. To improve self-care behavior, cooperation among doctors, health workers, and family support are needed in order to provide sustainable education and advocacy; so that, patients with Type 2 diabetes will be more understanding and independence.

\section{ACKNOWLEDGEMENT}

I would like to extend my appreciation to the Rector of Sumatra Utara University and the Dean of the Faculty of Medicine, Sumatra Utara University.

\section{REFERENCE}

[1] H.T.G Faria, V.S Veras, A.T.F Xavier, C.R.S Teixeira, M.L Zanetti, and M.A Santos. Quality of life in patients with diabetes mellitus before and after their participation in an educational program. Rev Esc Enferm USP, 47(2), pp.344-9, 2012

[2] Y.Y Hou, W. Li, J. B Qiu and X. H Wang. Efficacy of blood glucose self-monitoring on glycemic control in patients with non-insulintreated type 2 diabetes: A meta-analysis. International Journal of Nursing Sciences I, pp.191-5, 2014

[3] T. Bonner, M. Foster, and E. Spears-Lanoix E. Type 2 Diabetes Related Foot Care Knowledge And Foot Self-Care Practice Interventions In The United States: A Systematic Review Of The Literature. Diabetic Foot \& Ankle 2016, 7: 29758, 2016

[4] A.K SigurdardottirSelf-Care In Diabetes : Model Of Factors Affecting Self Care. Journal Of Clinical Nursing, 14, 301-3014, 2015

[5] V.D Sousa, and J.A Zauszniewski. Toward A Theory Of Diabetes Self-Care Management. The Journal Of Theory Construction \& Testing, 9 (2), 61-67, 2005

[6] Steinsbekk, Aslak et al. "Group Based Diabetes Self-Management Education Compared to Routine Treatment for People with Type 2 Diabetes Mellitus. A Systematic Review with Meta-Analysis.” BMC Health Services Research 12 (2012): 213. PMC. Web. 27 Nov. 2016.

[7] Y. Kusniyah, R. Nursiswati. Hubungan tingkat dengan tingkat HbA1C pada klien diabetes melitus tipe 2 di poliklinik endokrin RSUP.dr. Hasan Sadikin Bandung, 2010, Available : http://pustaka.unpad.ac.id. [Accesed 11 April 2015].

[8] American Association of Diabetes Educators. AADE7 Self-Care Behaviors, 2010. Accessed 21 September 2016 from https://www.diabeteseducator.org/patient-resources/aade7-self-carebehaviors

[9] Zareban I, Karimy M, Niknami S, Haidarnia A, Rakhshani F. The effect of self-care education program on reducing HbAlc levels in patients with type 2 diabetes. J Edu Health Promot [serial online] 2014 $\begin{array}{llll}\text { [cited } 2016 & \text { Nov } & \text { Available }\end{array}$ from: http://www.jehp.net/text.asp?2014/3/1/123/145935

[10] Association for Clinical Biochemistry and Diabetes United Kingdom. Standardisation of the Reference Method for the Measurement of HbA1c to Improve Diabetes Care, London: The Association for Clinical Biochemistry and Diabetes United Kingdom, 2013

[11] L.A Khan and S.A Khan SA. Level of knowledge and self-care in diabetes in a community hospital in Najran. Ann Saudi Med. 2000;20:300-1. 2000

[12] K. Ayele, B. Tesfa, L. Abebe, T. Tilahun, E. Girma. Self care behavior among patients with diabetes in Harari, Eastern Ethiopia: The health belief model perspective. PLoS ONE 7(Martin et al.): e3551, 2012

[13] Florkowski C. $\mathrm{HbA}_{1 \mathrm{c}}$ as a Diagnostic Test for Diabetes Mellitus Reviewing the Evidence. The Clinical Biochemist Reviews. 2013;34(2):75-83.

[14] W. Aditama. The relationship of self-care, self efficacy, and social support with glycemic control(hba1c) among type-2 diabetes mellitus patients in Banyudono 1 and Ngemplak public health centres in Boyolali district central java province. Thesis, Postgraduate Program Faculty Of Medicine, Gadjah Mada University, 2011

[15] Shrivastava, S. R., Shrivasta, P. S., \& Ramasay, J. 2013. Role of safecare in management of diabetes mellitus. Journal of Diabetes \& Metabolic Disorders 2013, 12:14 Available: 
http://www.jdmdonline.com/content/12/1/14. [Accesed 29 Maret 2015].

[16] M.F Farahani, Z. Purfarzad, M. Ghorbani, Z.G Zare, F. Ghorbani . The impact of Multimedia Software Support on the Knowledge and SelfCare Behaviors of Patients with Type 2 Diabetes: a Randomized Clinical Trial. Journal of Caring Sciences, June 2016; 5 (2), 111-120

[17] R. Zuniga. The Influence Of Group Medical Visits On Patients' Behavioral Intentions, Self-Management Behaviors, And Clinical Outcomes. Presented to the Faculty of the University of Alaska Anchorage and the University of Alaska Fairbanks, 2013

[18] R.R Rubin. Diabetes and Quality of Life. Diabetes Spectrum, 13(2000), pp.21, 2000

[19] L. Von Arx, H. Gydesen dan S. Shovland S.Treatment belief, health behavior, and their association with treatment outcome in Type 2 diabetes. BMJ Open Diabetes Res Care, 2016;4(1):e00016

[20] Gao et al.. Effects of self-care, self-efficacy, social support on glycemic control in adults with type 2 diabetes. BMC Family Practice; 14:66. Med. 2000;20:300-1, 2013 